Bangladesh J. Plant Taxon. 25(1): 107-111, 2018 (June)

(C) 2018 Bangladesh Association of Plant Taxonomists

\title{
LECTOTYPIFICATION OF CRYPTOCARYA ANAMALAYANA GAMBLE (LAURACEAE) WITH A NOTE ON ITS FRUITS
}

\author{
K.H. Amitha Bachan ${ }^{1}$, A.J. Robi ${ }^{2}$ A.K. PradeEP ${ }^{3}$ and P.S. Udayan ${ }^{4}$ \\ Research Department of Botany, MES Asmabi College, P.Vemballur Post, \\ Kodungallur Thrissur, Kerala 680671, India
}

Keywords: Cryptocarya anamalayana; Lectotype; Western Ghats; Lauraceae.

The genus Cryptocarya comprises about 350 species, most of which are confined to tropical Asia (Van der Werff, 2008). In the Indian subcontinent, the genus is represented by 15 species, of which 6 are known to be distributed in the Western Ghats of southern India (Gangopadhyay and Chakrabarty, 2005). During the course of an assessment of the riparian flora of the Chalakkudy river basin the authors collected an interesting specimen of Cryptocarya from the Sholayar, the Cryptocarya anamalayana Gamble.

Gamble (1925) described this species based on two specimens from Anamalai hills of southern India [Anamalai hills, June 1872, R.H. Beddome 270 (K000768404, image!) and Punachi, Coimbatore, May 1903, C.A. Barber 6008 (CAL!] without any fruiting specimen, and hence recorded "fructus ignotus" (Fruit unknown) in the protologue. Subsequently, the genus in the Indian subcontinent was revised by Gangopadhyay and Chakrabarty (2005). They also cited both the specimens originally cited by Gamble in the protologue simultaneously as types. Hence, one among them may be selected to serve as the lectotype of the species according to article 9.2, 9.11 and 9.12 of the ICN (McNeill et al., 2012). Consequently, the specimen collected by Beddome in June 1822 (Beddome 270, K000768404, image!) from Anamalai hills bearing a determinavita slip, and drawing of its floral parts in Gamble's own handwriting on the sheet is designated here as the lectotype.

No mature fruiting specimens of this species were collected or described so far by any of the subsequent authors (Mohanan and Henry, 1994; Sasidharan, 1997; Gangopadhyay and Chakrabarty, 2005), and hence the morphological features of fruits are described here for the first time based on a specimen collected from a place close to the type locality. Lectotype of Cryptocarya anamalayana Gamble (Lauraceae) is designated here along with description of its mature fruits.

Cryptocarya anamalayana Gamble, Bull. Misc. Inform. Kew 1925: 126 (1925); Fl. Madras: 1218 (1925); V. Chandras. in A.N. Henry et al., Fl. Tamil Nadu 2: 209 (1987); M. Mohanan \& A.N. Henry, Fl. Thiruvananthapuram: 393 (1994); Sasidh., Biodiv. Doc. Kerala: Fl. Pl.: 397 (2004); M. Gangop. \& Chakrab., J. Econ.Taxon. Bot. 29(2): 278 (2005); P.S.S. Rich. \& Muthuk., Check List 8(5): 951 (2012).

(Figs 1 \& 2).

Lectotype (designated here): India. Tamil Nadu: Anamalai hills, June 1872, $3000 \mathrm{ft}$, R.H. Beddome 270 (K000768404, image!).

\footnotetext{
${ }^{1}$ Corresponding author. Email: amithabmes@gmail.com

${ }^{2}$ Department of Botany, Bishop Abraham Memorial College, Thuruthicad Post, Pathanamthitta, Kerala689597, India.

${ }^{3}$ Department of Botany, University of Calicut, Calicut University P.O. 673635, Kerala, India.

${ }^{4}$ P.G. Department of Botany, Sree Krishna College, Ariyannur P.O., Guruvayur, Thrissur, Kerala 680102 , India.
} 
Evergreen tree, 7-16 m high; bark greyish brown outside, orange-brown inside with creamy white blaze; branchlets golden reddish, dark brown when dry, subterete, tawny-velutinous to fulvous-tomentose. Leaves simple, alternate, elliptic, obovate to obovate-oblong, 8-24×4-11 cm, obtusely cuneate to subacute at base, obtusely acute to apiculate at apex, margin entire, dark green, turning dark brown when dry, glossy above, pale greyish green, turning reddish green when dry, glaucous to glaucescent beneath; midrib slightly sunken, tawny-tomentose or velutinous above, fulvous to brown-tomentose or villous beneath; lateral veins 6-10 pairs, impressed above, highly elevated beneath, sub-opposite and subparallel, arcuate and slightly looped towards margin; petiole $6-12 \times 2-5 \mathrm{~mm}$, sulcate above, tawny-velutionous or rusty tomentose; intercostae scalariform and prominent as midrib, finely reticulate, inconspicuous above, highly raised beneath, percurrent. Inflorescence axillary or sub-terminal, $2-6 \mathrm{~cm}$ long cymose panicles, rusty or tawnyvelutionous or villous; bracts and bracteoles ovate-acute, c. $3.0 \times 1.5 \mathrm{~mm}$, rusty-villous; lateral flowers of the cymes sub-opposite. Flowers bisexual, c. $4 \mathrm{~mm}$ long, densely rufous-tomentose; perianth tube narrowed towards apex; perianth lobes 6 , in 2 whorls $(3+3)$, ovate, $1.5-2.5 \times c .1 .0$ $\mathrm{mm}$, acute, densely rufous-tomentose outside, appressed-pilose inside; stamens 9 in 3 whorls $(3+3+3)$, perfect, $1.0-1.6 \mathrm{~mm}$ long; anthers ovate, obtuse, 2-locular; filaments up to $1 \mathrm{~mm}$ long, slender, densely villous; outer two series eglandular, introrse; third series glandular and extrorse with 2 glands at base; glands sessile, orbicular, c. $0.5 \mathrm{~mm}$; staminodes c. $1 \mathrm{~mm}$ long, deeply cordate, shortly stipitate, acuminate at apex, villous at base. Ovary c. $1.5 \mathrm{~mm}$ long, sessile, glabrous; style c. $1 \mathrm{~mm}$ long, slender, glabrous; stigma capitate. Berries oblongoid to slightly oblong-obovoid, $2.5-4.0 \times 0.8-1.3 \mathrm{~cm}$, obtuse at ends, longitudinally 10-12-ribbed, sparsely pubescent, light to bright green when young, glossy black when ripe; fruiting pedicels $2-4 \mathrm{~mm}$ long, velutinous-tomentose. Seed solitary, oblanceoloid, $2.0-3.5 \times 0.5-1.0 \mathrm{~cm}$, obtuse at base, obtusely acute at apex, slightly constricted below the middle, smooth, yellowish brown.

Flowering and fruiting: April to August.

Habitat: The species is very rare in evergreen and wet evergreen forests on hillslopes at elevations ranging from 600 to $1200 \mathrm{~m}$ in the four locations of Southern Western Ghats. The present collection is only of a few trees growing along wet evergreen forest slopes with streams draining to the river or reservoir.

Distribution: Endemic to southern Western Ghats (Kerala and Tamil Nadu) at four disjunct locations: Thiruvananthapuram (Mohananand Henry, 1994), Shenduruni Wildlife Sanctuary (Sasidharan, 1997), eastern slope of Valayar (Gangopadhyay and Chakrabarty, 2005) and Sholayar forests, Kerala part of Anamalais (Bachan, 2011).

Conservation status: Endangered B1+2c, only few trees (12 Nos.) were located from the Sholayar region, near to the reservoir along stream banks during the present study (IUCN, 1998). The species is misspelled in IUCN Red List as Cryptocarya anamallayana Gamble.

Specimens examined: India, Kerala: Kollam district: Kallar, 13 April 1993, N. Sasidharan 10361 (KFRI); Alvarkurichi, 18 February 1995, N. Sasidharan 11419 (KFRI); Thrissur district: Sholayar, Kerala part of Anamalai hills, Chandanthodu, $800 \mathrm{~m}, 10.314122^{\circ} \mathrm{N}, 76.783300^{\circ} \mathrm{E}, 28$ November 2004, Amitha Bachan 98740 (CALI); ibid., 27 April 2006, Amitha Bachan 98840; Sholayar, Chandanthode, 20 April 2010, P.S. Udayan et al. 6726, 6734 (CMPR); Sholayar, Kerala part of Anamalai hills, Chandanthodu, $808 \mathrm{~m}, 10.31323^{\circ} \mathrm{N}, 76.77735^{\circ} \mathrm{E}, 19$ August 2014, Amitha Bachan 137305 (CALI).Tamil Nadu: Tirunelveli district: Eastern slope of Valayar, 12 July 1976, Bhargavan 47462 (CAL). 


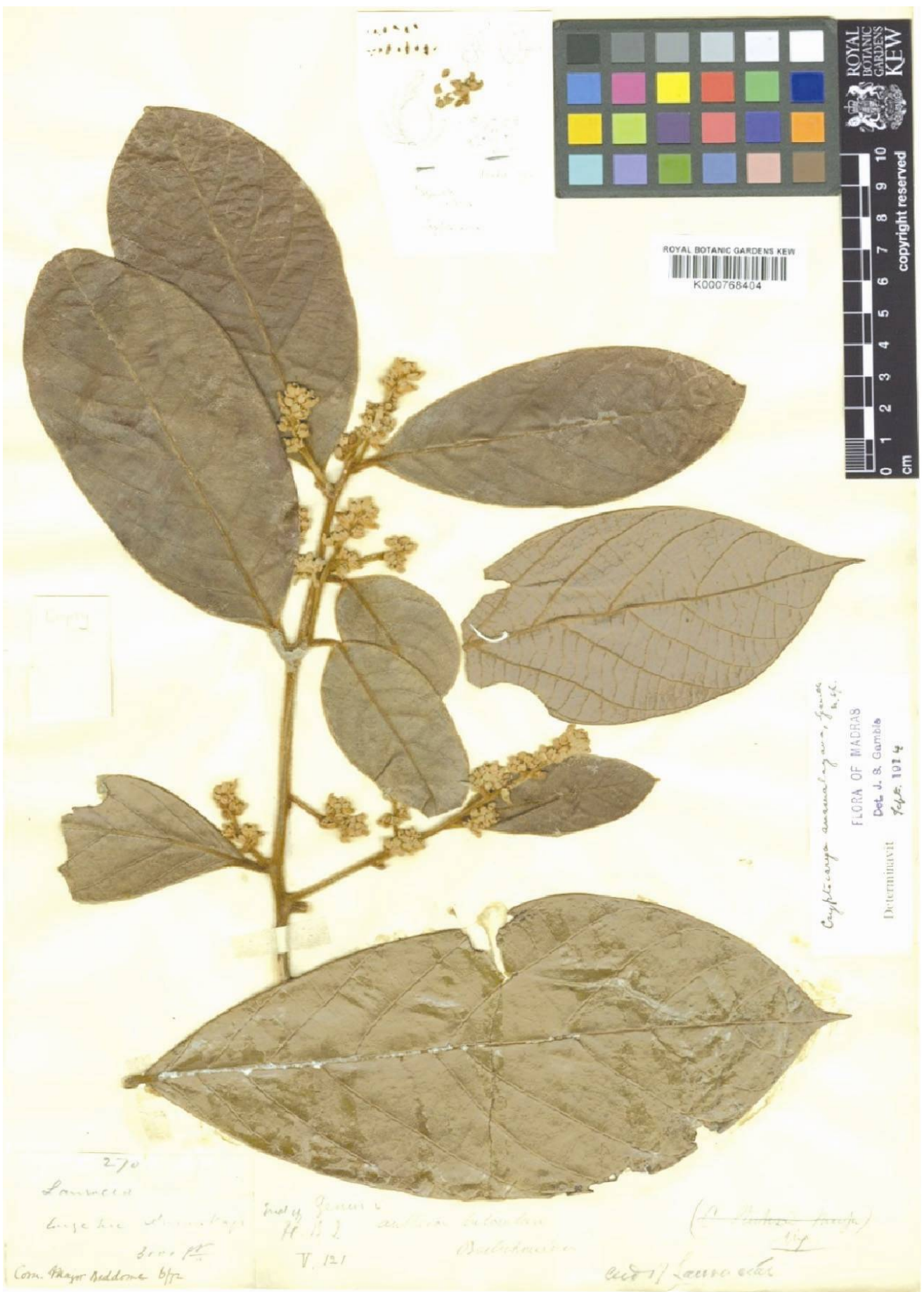

Fig. 1. Lectotype of Cryptocarya anamalayana Gamble [Beddome 270] [@ The Board of Trustees of the Royal Botanic Gardens, Kew. Reproduced with permission] 

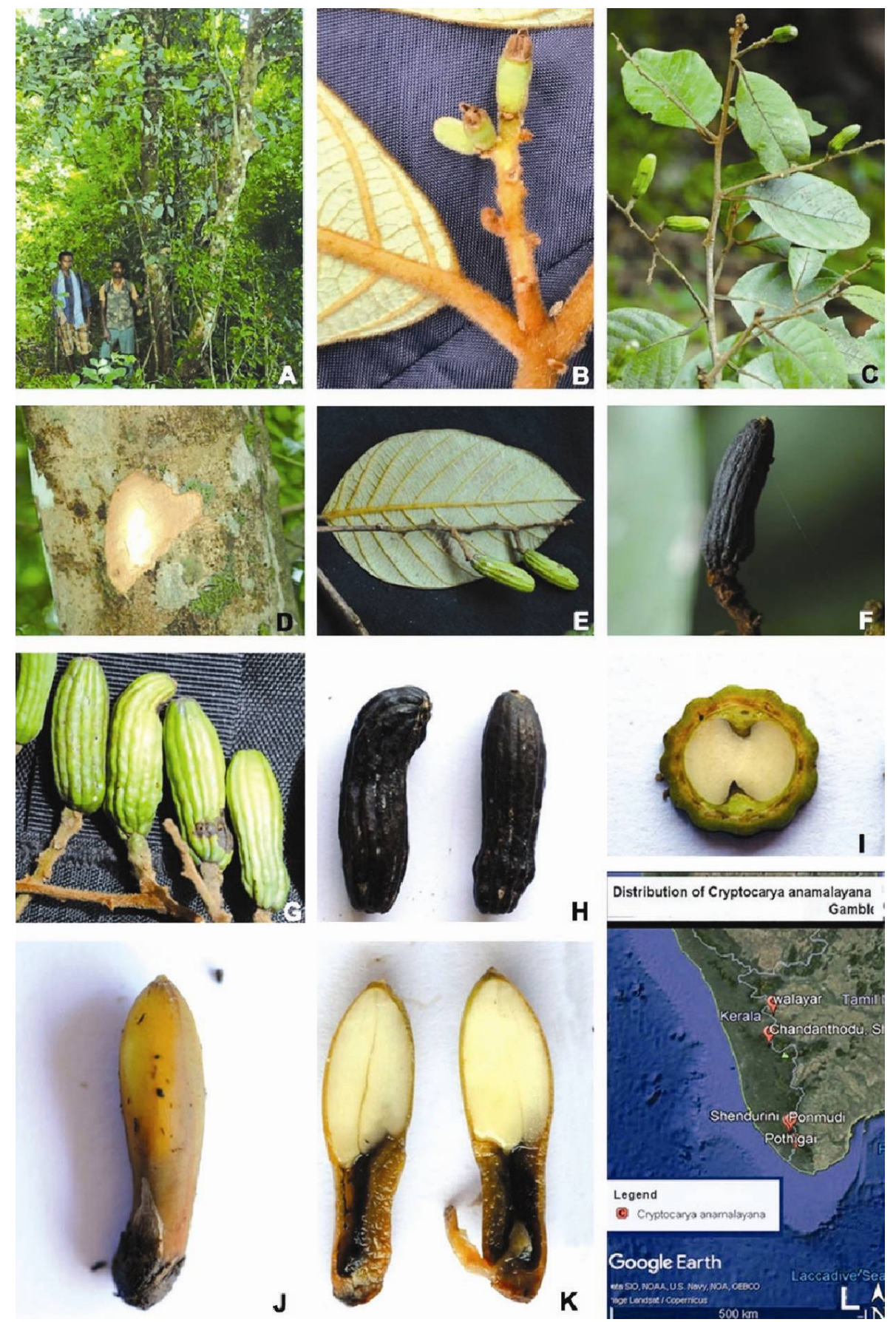

Fig. 2. Cryptocarya anamalayana Gamble. A. Habitat; B. Rusty tomentose leaf (abaxial surface) and young branchlets; C. Fruiting twig; D. Bark showing blaze; E\&G. Mature fruits; F\&H. Ripened fruits; I. C.S. of fruit; J. Seed; K. L.S. of seed; L. Distribution map. 


\section{Acknowledgements}

The authors are thankful to Kerala State Forest Department for granting permission to carry out research in the forests, Western Ghats Hornbill Foundation and the Kadar tribes of Vazhachal forests for various help. The first author would like to acknowledge the financial support from UGC Minor Research, Sunya Foundation Ahemedabad for PhD and CEPF-ATREE Western Ghats Small Grants for conservation. The second author would like to thank Department of Science and Technology, Government of India. Thanks are also due to the anonymous reviewers and Trustees of the Royal Botanical Garden, Kew.

\section{References}

Bachan, A.K.H. 2011. Riparian Flora of the Chalakkudy River Basin and its Ecological Significance. PhD Thesis, Calicut University, Kerala, 876 pp.

Gamble, J.S. 1925. New Lauraceae from Southern India. Bull. Misc. Inform. Kew 3(XVI): 126-132.

Gangopadhyay, M. and Chakrabarty, T. 2005. The genus Cryptocarya R. Br. (Lauraceae) in Indian Subcontinent. J. Econ. Taxon. Bot. 29(2): 274-293.

IUCN 1998. Cryptocarya anamallayana. The IUCN Red List of Threatened Species 1998: e.T38783 10144625.http://dx.doi.org/10.2305/IUCN.UK.1998.RLTS.T38783A10144625.en. (Accessed on 29 March 2018).

McNeill, J., Barrie, F.R., Buck, W.R., Demoulin,V., Greuter, W., Hawksworth, D.L., Herendeen, P.S., Knapp, S., Marhold, K., Prado, J., Prudhomme, W.F., Reine, V., Smith, G.F., Wiersema, J.H. and Turland, N.J. 2012. International Code of Nomenclature for algae, fungi, and plants (Melbourne Code).Adopted by the Eighteenth International Botanical Congress Melbourne, Australia, July 2011. Regnum Vegetabile 154: 1-240.

Mohanan, M. and Henry, A.N. 1994. Flora of Thiruvananthapuram, Kerala. Botanical Survey of India, Coimbatore, $621 \mathrm{pp}$.

Sasidharan, N. 1997. Flora of Shendurini Wildlife Sanctuary. Research Report, Kerala Forest Research Institute, Peechi, $267 \mathrm{pp}$.

Van der Werff, H. 2008. A new species and new combinations in Cryptocarya from Madagascar. Adansonia 30(1): 41-46. 